\title{
Photosynthetic picoplankton in French Polynesian atoll lagoons: estimation of taxa contribution to biomass and production by flow cytometry
}

\author{
L. Charpy ${ }^{1, *}$, J. Blanchot ${ }^{2}$ \\ ${ }^{1}$ ORSTOM, COM, Traverse de la Batterie des Lions, F-13007 Marseille, France \\ ${ }^{2}$ ORSTOM, CNRS, Station Biologique, BP 74, F-29682 Roscoff, France
}

\begin{abstract}
Picophytoplankton was studied by flow cytometry in 11 Tuamotu (French Polynesia) atoll lagoons and in the surrounding ocean. The respective contribution of Prochlorococcus, Synechococcus and picoeukaryotes on biomass and primary production was evaluated. Red fluorescence was demonstrated to be a proxy for chlorophyll. The relative sizes of the 3 picoplankton groups were estimated using forward light scattering measured in Takapoto lagoon on living cells. The average diameters for Prochlorococcus, Synechococcus and picoeukaryotes were estimated as $0.62 \pm 0.08$ (SD), $0.89 \pm 0.09$ and $3.11 \pm 0.22 \mu \mathrm{m}$, respectively. The lowest values occurred before sunrise and the highest in the afternoon. Cellular carbon content was estimated using C/biovolume ratios from the literature. The average biomass for Prochlorococcus, Synechococcus and picoeukaryotes was calculated as $60 \pm 20$, $178 \pm 52$ and $4695 \pm 834 \mathrm{fg} \mathrm{C}$ cell $^{-1}$ respectively. Synechococcus formed the predominant group in terms of abundance and carbon biomass and had the highest planktonic primary production in most lagoons. As it is generally scarce in deep water with limited light availability, its biomass contribution was reduced in deep lagoons. Average lagoonal picoplankton abundance varied by a factor of 200 for the different populations and was affected by the geomorphology of the atolls. In very shallow lagoons, no general trend could be observed, as the dominant group appeared to depend on the water renewal rate within the lagoon. In the surface layer of the surrounding ocean the community structure was dominated by Prochlorococcus. However, the observed percentage of Synechococcus (>10\%) is usual for the coastal zone. In the upper $120 \mathrm{~m}$ of ocean waters surrounding Takapoto, the integrated picoplankton biomass (1242 $\mathrm{mg} \mathrm{C} \mathrm{m}^{-2}$ ) consisted of $65 \%$ Prochlorococcus, $1 \%$ Synechococcus and $34 \%$ picoeukaryotes.
\end{abstract}

KEY WORDS: Flow cytometry · Cyanobacteria Prochlorococcus - Chlorophyll Primary production Atoll lagoons . Diurnal cell size variations

\section{INTRODUCTION}

In its intertropical zone, the Pacific Ocean harbors hundreds of coral atolls and the profusion of life is noteworthy in these oligotrophic waters. A number of these islands are located in the South Pacific. In the Tuamotu archipelago (French Polynesia), many atolls are inhabited and sea farming of black pearl oyster Pinctada margaritifera, which feed on phytoplankton, is a major economic activity. Much research has stud-

\footnotetext{
•E-mail: Icharpy@com.univ-mrs.fr
}

ied the community structure of phytoplankton, evaluated primary production and investigated the nature of the food particles aggregated by oysters. In these coral reef lagoons, small phytoplankton cells identified as prokaryotic Synechococcus sp. (Blanchot et al. 1989, Charpy et al. 1992) dominate larger cells both in terms of biomass and primary production (Charpy 1996). Nevertheless the heterogeneity in the water column can lead, under certain circumstances, to the local dominance in biomass and primary production of picoeukaryotes (Charpy \& Blanchot 1996). In addition, small populations of Prochlorococcus in the lagoon waters of the closed atoll Takapoto have been 


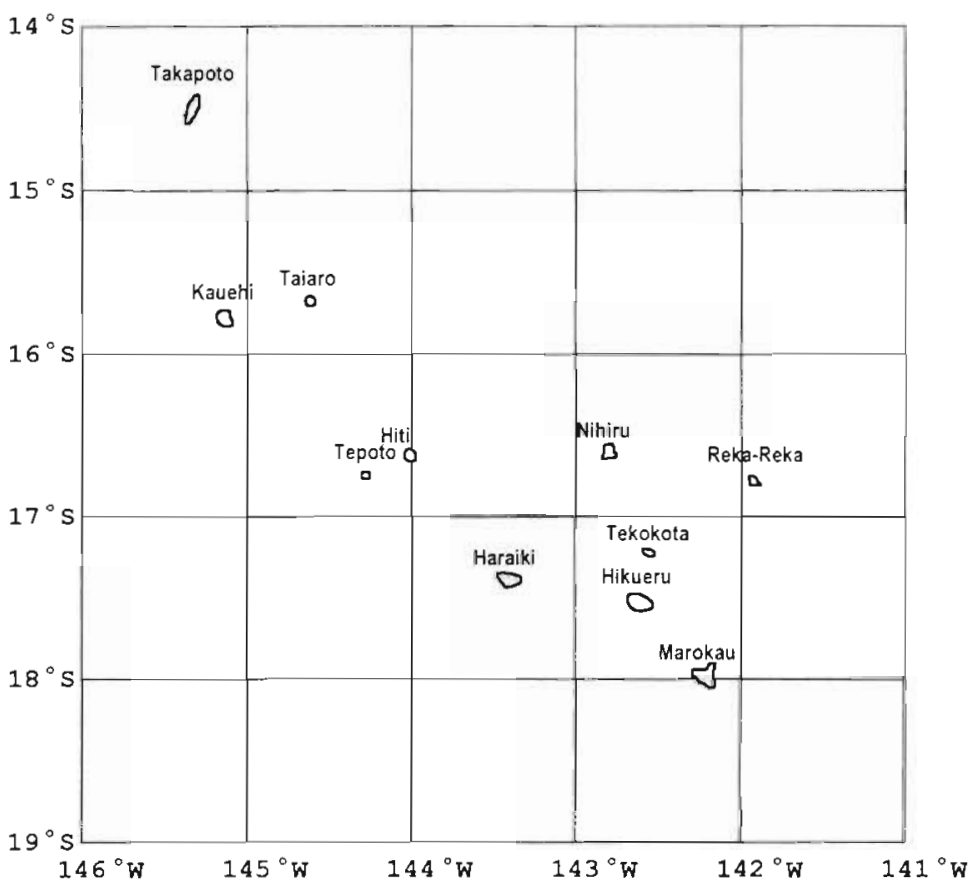

Fig. 1. Location of investigated atolls in French Polynesia

described (Charpy \& Blanchot 1996). These reports show a diversity of community structure in several atoll lagoons and raise the question as to which biological or geomorphological force drives this system. Several studies in Tuamotu Archipelago (CYEL: Charpy 1992; TYPATOLL: Dufour \& Harmelin-Vivien 1997) have contributed to our understanding of the relationships among picoplankton populations and of their distribution patterns, as well as the relationships between atoll geomorphology and picoplankton community structure. A classification of phytoplankton cell number, carbon biomass, chlorophyll biomass and primary productivity by size was established according to Li's method (1995). As cell abundance does not take into consideration the large difference in cell size of the 3 groups, we estimated the relative size of cells by using forward scatter as an index of size. We then computed the carbon content of cells using the relationship between cell volume and carbon. In order to estimate the contribution of each photosynthetic group to total chlorophyll biomass and production, we considered total red fluorescence to be a proxy for chlorophyll a. We used chlorophyll size fractionation to calculate the contribution of each population to primary productivity.

\section{MATERIAL AND METHODS}

Sampling. The location of the 11 investigated atolls appears on Fig. 1 and their characteristics are given in Table 1 . Water samples were collected with acid-cleaned Niskin bottles at the surface and at $5 \mathrm{~m}$ depth intervals down to a maximum depth of $30 \mathrm{~m}$. Phytoplankton biomass in Takapoto was sampled in November 1994 at 6 (Stns 1, 2, 3, 6, 7 and 8 ) of the 8 stations investigated during the CYEL program within the lagoon (Charpy 1996) and at 1 ocean site for a total of $15+1$ profiles (Fig. 2). Sampling in the ocean was at 5, 20,30, $50,60,80,90,100,110,120$ and $150 \mathrm{~m}$ depth. Within the TYPATOLL program 10 atoll lagoons were studied in November 1995 and March 1996. For each lagoon, surface samples were collected at triplicate sites in 5 areas located in the north, south, east and west quad-

Table 1. Characteristics of the 11 investigated atolls during the PGRN, CYEL and TYPATOLL programs. $\mathrm{S}_{\mathrm{at}}=$ atoll area; $\mathrm{S}_{\text {lag }}=$ lagoon area $\left(\mathrm{km}^{2}\right) ; \mathrm{NP}=$ number of inlets into the lagoon; EAD = estimated average depth $(\mathrm{m}) ;$ Ope = Opening = linear extent of channels/linear extent of barrier reef; Inh. $=$ no. of inhabitants $;$ Expl. = marine commercial exploitation

\begin{tabular}{|lccrrrrrrrl}
\hline Atoll & Latitude & Longitude & $S_{\text {at }}$ & $S_{\text {lag }}$ & NP & EAD & Ope & Inh. & Expl. & Source \\
\hline Haraiki & $17^{\circ} 28^{\prime} \mathrm{S}$ & $143^{\circ} 26^{\prime} \mathrm{W}$ & 24.6 & 10.4 & 1 & 10 & 19 & 20 & & \\
Hikueru & $17^{\circ} 35^{\prime} \mathrm{S}$ & $142^{\circ} 38^{\prime} \mathrm{W}$ & 107 & 82 & 0 & 25 & 18 & 300 & Pearl \\
Hiti & $16^{\circ} 43^{\prime} \mathrm{S}$ & $144^{\circ} 06^{\prime} \mathrm{W}$ & 25 & 15 & 0 & 10 & 19 & 0 & & \\
Kauehi & $15^{\circ} 50^{\prime} \mathrm{S}$ & $145^{\circ} 09^{\prime} \mathrm{W}$ & 343 & 315 & 1 & 45 & 22 & 200 & Pearl & \\
Marokau & $18^{\circ} 03^{\prime} \mathrm{S}$ & $142^{\circ} 16^{\prime} \mathrm{W}$ & 256 & 217 & 1 & 30 & 17 & 50 & & \\
Nihiru & $16^{\circ} 41^{\prime} \mathrm{S}$ & $142^{\circ} 50^{\prime} \mathrm{W}$ & 100 & 80 & 0 & 20 & 25 & 20 & & \\
Reka-Reka & $16^{\circ} 50^{\prime} \mathrm{S}$ & $141^{\circ} 55^{\prime} \mathrm{W}$ & 52 & 7.4 & 0 & 1 & 2 & 0 & & Chevallier \& Salvat (1976), \\
Taiaro & $15^{\circ} 45^{\prime} \mathrm{S}$ & $144^{\circ} 38^{\prime} \mathrm{W}$ & 17.3 & 11.8 & 0 & 15 & 1 & 3 & & Poli \& Salvat (1976) \\
Takapoto & $14^{\circ} 30^{\prime} \mathrm{S}$ & $145^{\circ} 20^{\prime} \mathrm{W}$ & 104 & 81 & 0 & 25 & 2 & 500 & Pearl & Salvat \& Richard (1985) \\
Tekokota & $17^{\circ} 19^{\prime} \mathrm{S}$ & $142^{\circ} 34^{\prime} \mathrm{W}$ & 7.3 & 5.1 & 1 & 3 & 59 & 0 & & \\
Tepoto Sud & $16^{\circ} 49^{\prime} \mathrm{S}$ & $144^{\circ} 17^{\prime} \mathrm{W}$ & 6.2 & 1.6 & 1 & 5 & 15 & 0 & & \\
\hline
\end{tabular}




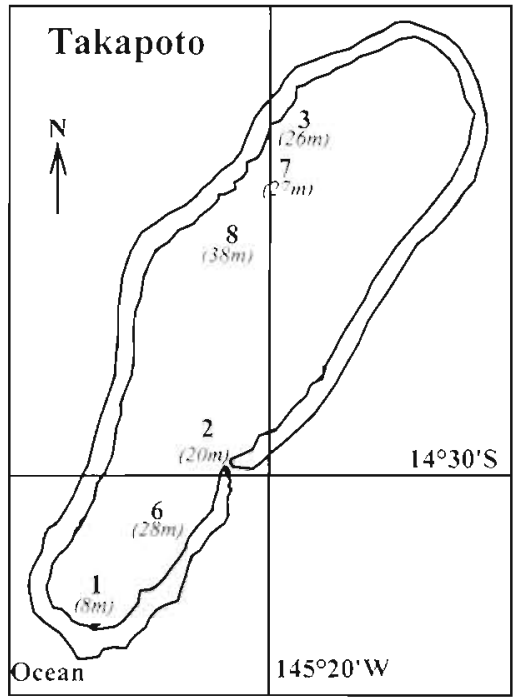

Fig. 2. Location of sampling stations investigated during the CYEL program in Takapoto lagoon (Stns 1 to 8 ) and the surrounding water (Stn 'Ocean')

rants as well as at the center of each lagoon in the morning. In addition, bottom samples were collected in the central area and surface samples at 6 ocean sites.

Light energy was measured with a LI-COR sensor (LI-190SA) fitted with a spherical probe.

Biomass and production measurements. Takapoto samples (November 1994) for population enumeration of live cells and for chlorophyll a (chl a) analyses were stored in an isotherm container in the dark. Filtration and size fractionation (total and $<1 \mu \mathrm{m}$ ) were completed within an hour of sampling. Enumeration of populations was performed according to Partensky et al. (1996) and Blanchot \& Rodier's (1996) methodology. Samples were counted with a Becton-Dickinson FACScan flow cytometer. The excitation source was a blue laser beam (15 $\mathrm{mW}, 488 \mathrm{~nm})$. The red fluorescence of the chlorophyll was analyzed at wave lengths $>650 \mathrm{~nm}$. In order to calibrate the optical measurements and to check the flow rate, known quantities of fluorescent beads (Polyscience, $2 \mu \mathrm{m}$ ) were added to each sample. List mode files were transferred to a microcomputer and analyzed on CYTOPC software (Vaulot 1989).

During TYPATOLL expeditions, we could not have the flow cytometer on board and samples were fixed with paraformaldehyde to a final concentration of $1 \%$ (modified from Vaulot et al. 1989). These samples were then kept in the dark for $10 \mathrm{~min}$, frozen in liquid nitrogen and stored at $-20^{\circ} \mathrm{C}$ for a few days, which can cause loss of cells. The analysis of the fixed material was conducted within a month of sampling. Partensky et al. (1996) estimated that most Prochlorococcus and Synechococcus were well preserved by this fixation method (loss ca 3 to $4 \%$ ) while picoeukaryotes were poorly preserved, with a cell loss of up to $23 \%$. They considered that the other flow cytometric parameters such as forward scatter were differently affected by the fixation, depending on the population type. In near-surface nitrate-depleted samples, Prochlorococcus populations are too dim to be completely resolved by the FACScan system, as has already been mentioned in the literature (Olson et al. 1990, Campbell \& Vaulot 1993, Shimada et al, 1993, Dusenberry \& Frankel 1994). Therefore, underestimation of dim Prochlorococcus was corrected in surface samples as reported by Blanchot \& Rodier (1996) and Charpy \& Blanchot (1996). Nevertheless an underestimation of cells could have occurred. In offshore cruises the dim Prochlorococcus were always restricted to oligotrophic areas, where divinyl chl a concentrations were weak. The weak red fluorescence is linked to a low cellular pigment content. The primary consequence of this is a possible underestimation of the fraction of biomass attributed to the Prochlorococcus.

Primary production measurements (clean technique; Fitzwater et al. 1982), chlorophyll determination and size fractionation (Nuclepore filters) were conducted according to Charpy (1996). All sub-samples used for measuring primary production were incubated between 10:00 and 14:00 $\mathrm{h}$ in $200 \mathrm{ml}$ polycarbonate bottles with $2 \mu \mathrm{Ci}$ of $\mathrm{H}^{14} \mathrm{CO}_{3}$. In Takapoto, samples were incubated in situ at $0,5,10,15,20$ and $25 \mathrm{~m}$ depth at Stn 6. At the other atolls, a deck incubator was used with flowing water and natural light. Incubation bottles were filtered successively through $3 \mu \mathrm{m}$ and $1 \mu \mathrm{m}$ Nuclepore filters and then $25 \mathrm{~mm}$ Whatman GF/F glass fiber filters. One bottle was filtered directly through $G F / F$ filters for an estimate of total production. To remove inorganic carbon $250 \mu$ of $0.5 \mathrm{~N} \mathrm{HCl}$ were added to the filter in the scintillation vial. After $12 \mathrm{~h}$, $100 \mu \mathrm{l}$ of Protosol were added to the filter. Radioactivity on the filters was measured with a liquid scintillation counter and corrected for quench using an internal standard and the channels ratio method

Chl a concentrations were determined by fluorometry (Yentsch \& Menzel 1963). The vacuum during fractionation never exceeded 0.004 atm. Fluorescence was measured before and after acidification with $50 \mu \mathrm{l}$ of $1 \mathrm{M} \mathrm{HCl}$. The fluorometer was calibrated using the SIGMA chl a standard. For chl a determinations a $250 \mathrm{ml}$ water sample was size fractionated using the same methods as for the productivity samples.

Estimating biomass and production from flow cytometry. Assuming that fluorescence is a proxy for chl $\boldsymbol{a}$, we can estimate the picophytoplankton biomass as chl a from in vivo red fluorescence (RF) (Yentsch \& 
Campbell 1991, Li et al. 1993, Shimada et al. 1993):

$$
\operatorname{chl} a=\sum_{i=1}^{3} n_{i} \times f_{i} \times \psi_{i}
$$

where $i$ refers to the 3 recognizable groups (i.e. Prochlorococcus, Synechococcus and picoeukaryotes); $n=$ cell concentration; $f=$ mean cell RF; $\psi=\mathrm{fg} \mathrm{chl}$ a per relative unit of RF.

Assuming that the $<1 \mu \mathrm{m}$ fraction consists primarily of prokaryotic cells (Charpy \& Blanchot 1996), we can also estimate the chlorophyll $<1 \mu \mathrm{m}$ using Eq. (2):

$$
\text { chl } a<1 \mu \mathrm{m}=\sum_{j=1}^{2} n_{i} \times f_{i} \times \psi_{i}^{\prime}
$$

where $\psi^{\prime}=$ fg chl $a<1 \mu \mathrm{m}$ per relative unit of RF.

It is also possible to estimate the picophytoplankton biomass as carbon. Indeed, it is commonly accepted that cellular carbon content is directly related to cell volume (Strathmann 1967):

$$
\mathrm{C}=\sum_{i=1}^{3} n_{i} \times v_{i} \times \alpha_{i}
$$

where $n=$ cell concentration; $v=$ mean average cell volume; $\alpha=$ carbon biomass to biovolume ratio.

In flow cytometric analyses of phytoplankton, it is common practice to regard forward (narrow angle) light scatter (FSC) as an index of cell size (Olson et al. 1993). A strong empirical correlation between FSC and Coulter volume using a wide variety of algae was demonstrated by Olson et al. (1989). These authors suggested that, at the low angles used by the flow cytometer to measure FSC, the influence of cell shape and refractive index was minor compared to that of cell size. We can therefore use FSC measured in Takapoto to estimate the cell sizes of the 3 picoplankton groups, assuming that they have a spherical shape and similar refractive indexes. The relation between FSC and the size of spherical particles in the size range of picophytoplankton (0.3 to $3 \mu \mathrm{m})$ can be written as (Morel 1991):

$$
\frac{\mathrm{FSC}_{\text {Cell }}}{\mathrm{FSC}_{\text {Beads }}}=\left(\frac{\text { Diameter }_{\text {Cell }}}{\text { Diameter }_{\text {Beads }}}\right)^{X}
$$

Assuming that, in a given biotope (lagoon, ocean), the exponent $x$ is the same for the 3 picoplankton groups, it can be estimated from a known value of cell diameter.

\section{RESULTS}

\section{Takapoto}

The averaged light profile from Takapoto lagoon is shown in Fig. 3. At $25 \mathrm{~m}$ depth (average depth of the lagoon) light energy was on average $7 \%$ of the surface light energy.

Picoplankton distribution was heterogeneous in the water column in the 11 profiles performed between November 4 and 9 at Stns 6 and 7 . In the upper $10 \mathrm{~m}$,

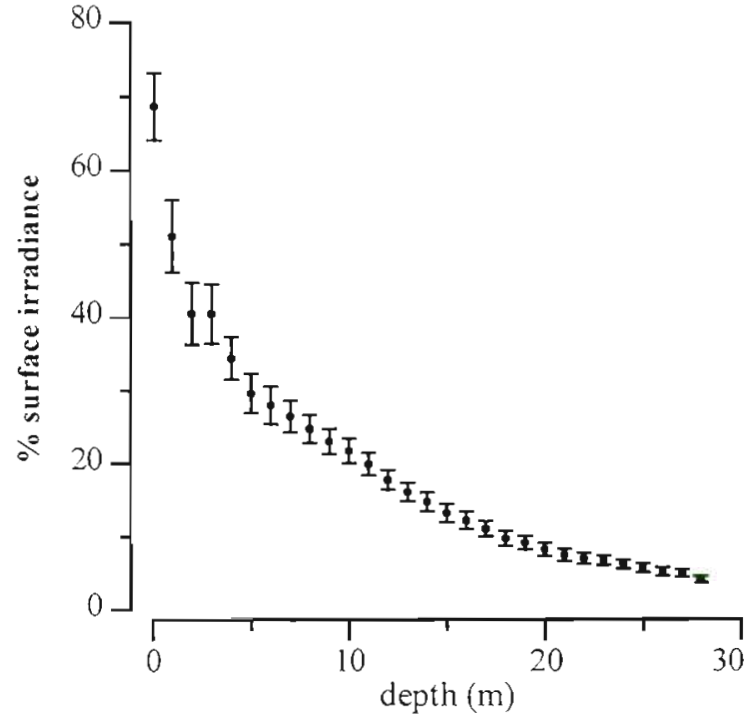

Fig. 3. Average \pm SE of the percentage of surface irradiance measured in Takapoto lagoon

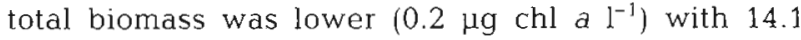
$\pm 1.1 \times 10^{3}$ Prochlorococcus $\mathrm{ml}^{-1}, 68.7 \pm 2.3 \times 10^{3}$ Synechococcus $\mathrm{ml}^{-1}$ and $2.7 \pm 0.01 \times 10^{3}$ picoeukaryotes $\mathrm{ml}^{-1}$. Below $10 \mathrm{~m}$, biomass was higher $\left(0.3 \mu \mathrm{g} \mathrm{chl} \mathrm{a} \mathrm{l^{-1 } )}\right.$ with $33.4 \pm 1.5 \times 10^{3}$ Prochlorococcus $\mathrm{ml}^{-1}, 141.1 \pm$ $7.7 \times 10^{3}$ Synechococcus $\mathrm{ml}^{-1}$ and $2.3 \pm 0.1 \times 10^{3}$ picoeukaryotes $\mathrm{ml}^{-1}$. In the entire column, $57 \pm 2 \%$ of the carbon assimilation rate was due to particles $<1 \mu \mathrm{m}$.

In the 4 remaining profiles, the water column was homogeneous.

\section{Estimating the contribution of the picoplankton groups to biomass as chl a}

The chl a content per unit of RF, $\psi_{j}$ and $\psi_{i}^{\prime}$ were estimated for 2 depth layers by regression using measured values of chl $a, \mathrm{chl} a<1 \mu \mathrm{m}, n$, and $f_{i}$ and using Eqs. (1) $\&(2)$ (Table 2). Values of $\psi_{i}$ and $\psi_{i}^{\prime}$ differed according

\begin{tabular}{|c|c|c|c|c|}
\hline & $\begin{array}{l}\text { Takapoto } \\
(0-10 \mathrm{~m})\end{array}$ & $\begin{array}{l}\text { Takapoto } \\
(15-30 \mathrm{~m})\end{array}$ & $\begin{array}{l}\text { Nov } 1995 \\
\text { (10 atolls) }\end{array}$ & $\begin{array}{l}\text { Mar } 1996 \\
\text { (10 atolls) }\end{array}$ \\
\hline$\Psi_{\text {Prochlorococrus }}$ & 13.7 & 111.0 & & \\
\hline$\psi_{\text {Synechococcus }}$ & 10.8 & 3.3 & & \\
\hline$\psi_{\text {plcoeukaryoles }}$ & 9.3 & 8.6 & & \\
\hline$\psi^{\prime}$ prochiorococcus & 15.6 & 128.5 & 43.7 & 49.3 \\
\hline$\psi^{\prime}$ Symechococus & 13.4 & 2.8 & 4.7 & 7.4 \\
\hline
\end{tabular}
to depth. The fit of data for individual layers was

Table 2. $\psi$ (fg chl a per unit RF) and $\psi^{\prime}$ (fg chl $a<1 \mu \mathrm{m}$ per unit RF) of the 3 picoplankton groups 

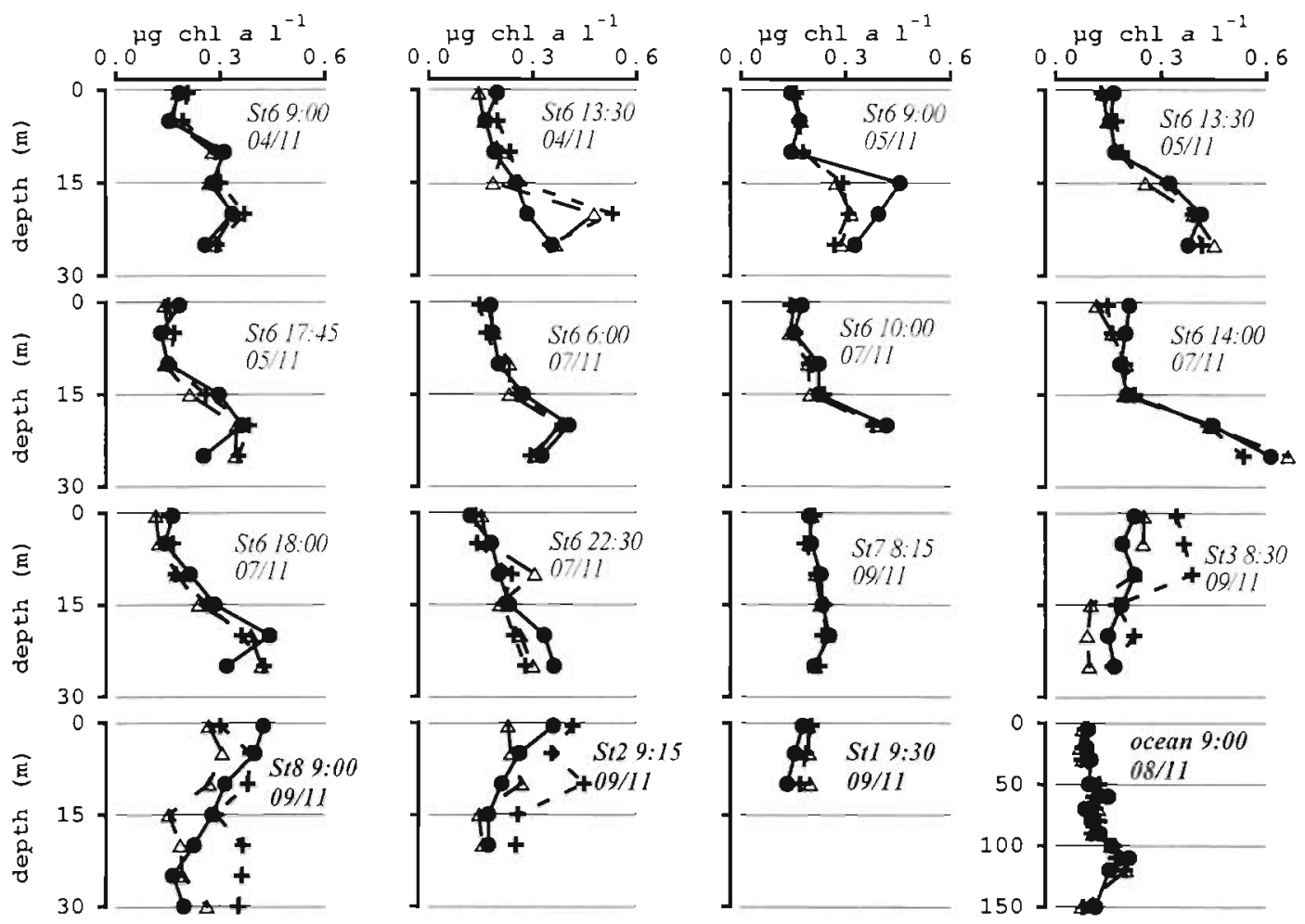

Fig. 4. Depth profiles of ( $)$ measured chl $a_{i}(+)$ fitted values of $\sum_{i=1}^{3} n_{1} \times f_{i} \times \psi_{i}$ and $(\Delta)$ fitted values of $\sum_{i=1}^{2} n_{1} \times f_{i} \times \psi_{i}{ }^{\prime}+c h l a>1 \mu m$ in Takapoto lagoon (November 1994)

extremely good in the first 11 profiles for total chl a $\left(\mathrm{R}^{2}=97.5\right.$ and $\mathrm{p}<0.01$ in both layers $)$ and chl $a<1 \mu \mathrm{m}$ $\left[R^{2}=92.6\right.$ in the upper layer $(0$ to $10 \mathrm{~m})$ and 92.7 in the deeper layer $(15$ to $30 \mathrm{~m}), \mathrm{p}<0.01$ ). The agreement between measured chl $a$ and fitted values of

$$
\sum_{i=1}^{3} n_{1} \times f_{j} \times \psi_{i}
$$

and between measured chl $a$ and fitted values of

$$
\sum_{i=1}^{2} n_{i} \times f_{i} \times \psi_{i}{ }^{\prime}+\operatorname{chl} a>1 \mu \mathrm{m}
$$

(Fig. 4) was very good. Using regression estimated values of $\psi_{i}$ and $\psi_{i}^{\prime}$, the percentage contributions to $\mathrm{chl} a$ and chl $a<1 \mu \mathrm{m}$ from each picoplankton group were calculated. In terms of total chl a, picoplankton in the upper layer consisted of $54 \pm 2 \%$ picoeukaryotes, $45 \pm 2 \%$ Synechococcus and $2 \pm 0 \%$ Prochlorococcus. In the same layer Synechococcus contributed $86 \pm 1 \%$ of chl $a<1 \mu \mathrm{m}$ and Prochlorococcus $14 \pm 1 \%$ of chl $a$ $<1 \mu \mathrm{m}$. In terms of total chl $a_{i}$ picoplankton in the deeper layer consisted of $32 \pm 2 \%$ picoeukaryotes, $33 \pm 1 \%$ Synechococcus and $35 \pm 1 \%$ Prochlorococcus. In this deeper layer, Prochlorococcus and Synechococcus contributed $59 \pm 1$ and $41 \pm 1 \%$ of chl $a<1 \mu \mathrm{m}$, respectively.
In the surrounding ocean waters, the 0 to $120 \mathrm{~m}$

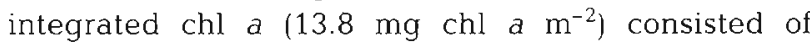
$11 \%$ Prochlorococcus, 34\% Synechococcus and 56\% picoeukaryotes.

\section{Estimating the sizes and cellular carbon contents of picoplankton groups}

Following Morel (1991) and Binder et al. (1996), we estimated the exponent $x$ of Eq. (4) using cytometric measurements and the average diameter of Synechococcus $(0.8 \mu \mathrm{m})$ measured at Takapoto with an optical microscope. Eq. (4) becomes:

$$
\frac{\text { FSC }_{\text {Cell }}}{\text { FSC }_{\text {Beads }}}=\left(\frac{\text { Diameter }_{\text {Cell }}}{\text { Diameter }_{\text {Beads }}}\right)^{X}=\left(\frac{0.8}{1.98}\right)^{X}
$$

We found for lagoonal waters $x=3.94$ and in the upper $100 \mathrm{~m}$ of oceanic waters $x=4.34$.

These values agree well with the theoretical expected values of Morel (1991), who reported that in the size range of picophytoplankton FSC varies from approximately $\mathrm{d}^{6}$ to $\mathrm{d}^{4}(\mathrm{~d}=$ dimension); thus, they were used to calculate cell size in lagoonal and oceanic populations. The carbon content of cells (Table 3 ) was estimated using the following volume to carbon conver- 
Table 3. Estimated diameter $(\mu \mathrm{m})$ and carbon content $(\mathrm{CC}$, $\mathrm{fg} \mathrm{C}$ cell-1 $)$ of the 3 picoplankton groups in Takapoto Iagoon. $\mathrm{SD}$ : standard deviation

\begin{tabular}{|c|c|c|c|c|c|c|}
\hline \multirow[t]{2}{*}{ Time } & \multicolumn{2}{|c|}{$\begin{array}{c}\text { Prochloro- } \\
\text { coccus }\end{array}$} & \multicolumn{2}{|c|}{$\begin{array}{l}\text { Synecho- } \\
\text { coccus }\end{array}$} & \multicolumn{2}{|c|}{$\begin{array}{c}\text { Pico- } \\
\text { eukaryotes }\end{array}$} \\
\hline & Size & $\mathrm{Cc}$ & Size & $\mathrm{Cc}$ & Size & $\mathrm{Cc}$ \\
\hline $06: 00 \mathrm{~h}$ & 0.54 & 39 & 0.81 & 129 & 2.93 & 3999 \\
\hline $10: 00 \mathrm{~h}$ & 0.60 & 53 & 0.90 & 180 & 3.18 & 4970 \\
\hline $14: 00 \mathrm{~h}$ & 0.73 & 94 & 0.99 & 239 & 3.26 & 5289 \\
\hline $18: 00 \mathrm{~h}$ & 0.67 & 73 & 0.96 & 218 & 3.33 & 5571 \\
\hline $22: 00 \mathrm{~h}$ & 0.56 & 43 & 0.80 & 124 & 2.83 & 3645 \\
\hline Lagoon average & 0.62 & 60 & 0.89 & 178 & 3.11 & 4695 \\
\hline $\mathrm{SD}$ & 0.08 & 23 & 0.09 & 52 & 0.22 & 834 \\
\hline Ocean (surface) & 0.6 & 53 & 0.92 & 191 & 2.47 & 2568 \\
\hline Ocean (5-100 m) & 0.6 & 53 & 0.82 & 135 & 2.34 & 2232 \\
\hline
\end{tabular}

sion factors (Verity et al. 1992): $470 \mathrm{fg} \mathrm{C} \mu \mathrm{m}^{-3}$ for

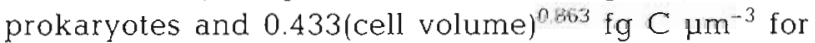
eukaryotes. During the period of our study picoplankton size and carbon content peaked at the beginning of the afternoon for prokaryotes and at the end of the afternoon for eukaryotes. This pattern of diurnal cell size variations appeared to be relatively independent of depth (Fig. 5). We calculated the carbon biomass of the 3 picoplankton groups by multiplying their cellular $\mathrm{C}$ content by their abundance. In the upper layer of the lagoon, the picoplankton $C$ biomass $\left(26 \mu \mathrm{g} \mathrm{l}^{-1}\right)$ consisted of 3\% Prochlorococcus, $47 \%$ Synechococcus and $50 \%$ picoeukaryotes while in the deeper layer, the picoplankton $\mathrm{C}$ biomass $\left(38 \mu \mathrm{g} \mathrm{l}^{-1}\right)$ consisted of $5 \%$ Prochlorococcus, 65\% Synechococcus and 30\% picoeukaryotes. In the upper $120 \mathrm{~m}$ of the ocean, integrated picoplankton biomass (1242 $\mathrm{mg} \mathrm{m}^{-2}$ ) consisted of $65 \%$ Prochlorococcus, $1 \%$ Synechococcus and $34 \%$ picoeukaryotes.

Estimating the contribution of picoplankton groups to primary production

The contribution of prokaryotic cells to total production can be estimated as the percentage of carbon assimilation rate in the $<1 \mu \mathrm{m}$ size fraction. Prokaryotic cells contributed $50.0 \pm 1.6 \%$ of carbon assimilation rate in the upper layer and $63.2 \pm 2.5 \%$ in the deeper layer. If we assume that the contributions of Prochlorococcus and Synechococcus to chl $a<1 \mu \mathrm{m}$ reflect their contributions to carbon assimilation rate $<1 \mu \mathrm{m}$, we can estimate their contributions to primary production by multiplying their contribution to chl $a<1 \mu \mathrm{m}$ by the proportion of carbon assimilation rate $<1 \mu \mathrm{m}$. The contribution of picoeukaryotes was estimated as the percentage of carbon assimilation rate $>1 \mu \mathrm{m}$. In the upper

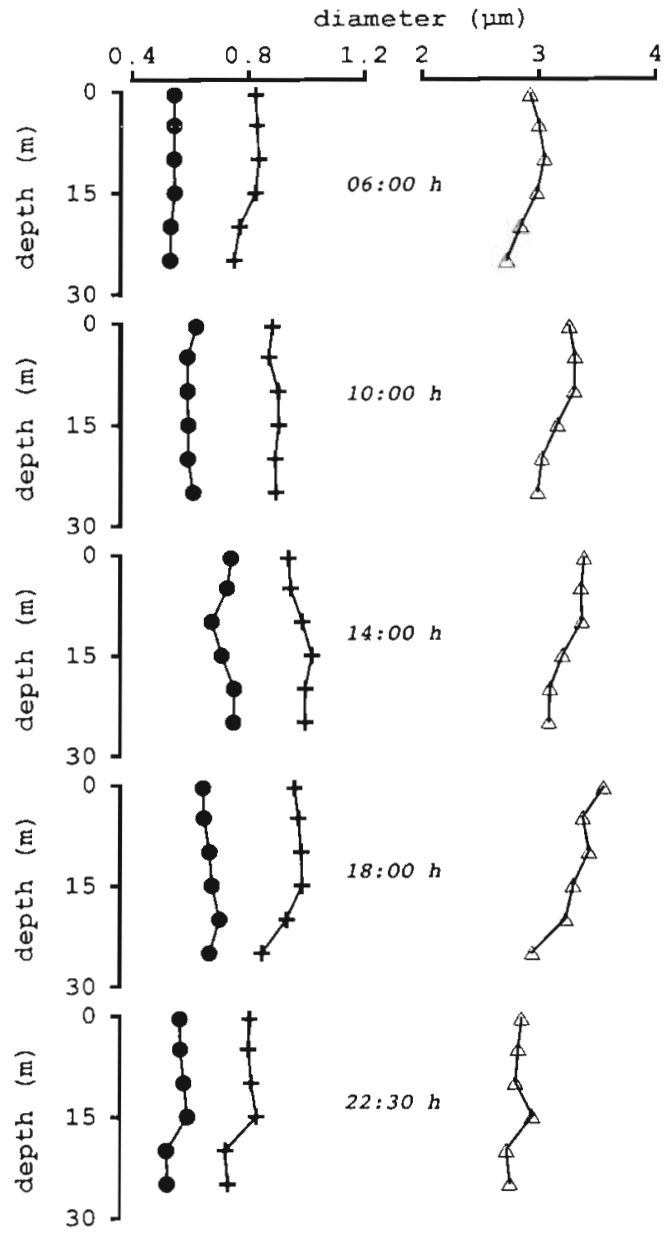

Fig. 5. Size of Prochlorococcus (•), Synechococcus $(+)$ and picoeukaryotes $(\Delta)$ at different hours of the day in Takapoto lagoon

layer, Prochlorococcus, Synechococcus and picoeukaryotes contributed $5.8 \pm 0.5,44.1 \pm 1.4$ and $50.0 \pm$ $1.6 \%$ respectively to primary production, whereas in the deeper layer they contributed $38.0 \pm 1.6,25.2 \pm$ 1.1 and $36.8 \pm 2.5 \%$ respectively to primary production.

\section{Other atolls}

Picoplankton biomass and production in the 10 atolls investigated during TYPATOLL

Highest phytoplanktonic chl a was observed in Reka-Reka atoll $\left(0.42 \mu \mathrm{g} \mathrm{l}^{-1}\right.$ in March and 0.57 in November). In the lagoons of Taiaro and Haraiki chl a concentrations were twice as high in March $\left(0.46 \mu \mathrm{g} \mathrm{l}^{-1}\right)$ as in November $\left(0.26 \mu \mathrm{g} \mathrm{I}^{-1}\right)$. The lowest chl a concentration was observed in Tekokota $(0.02$ to 


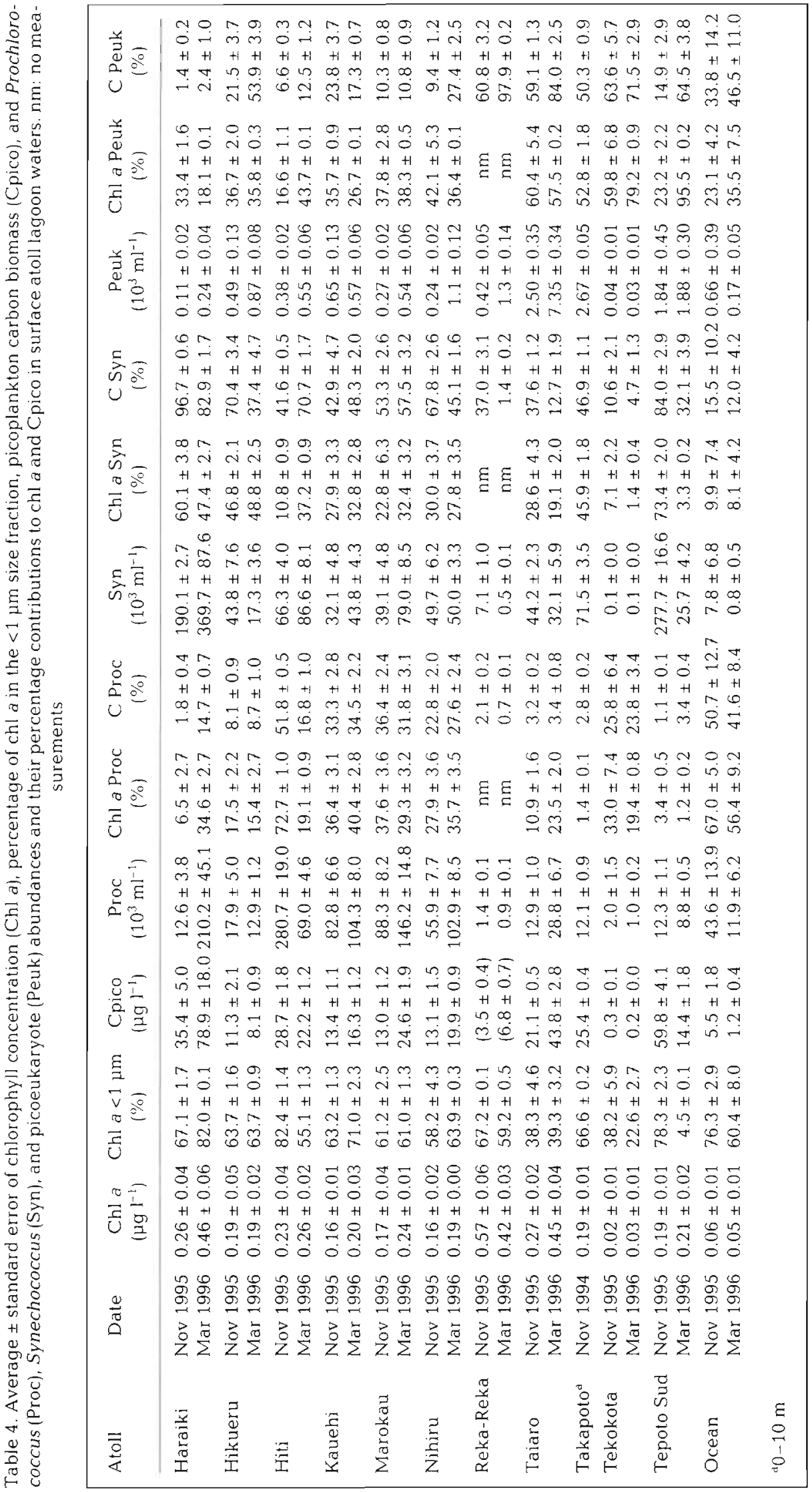



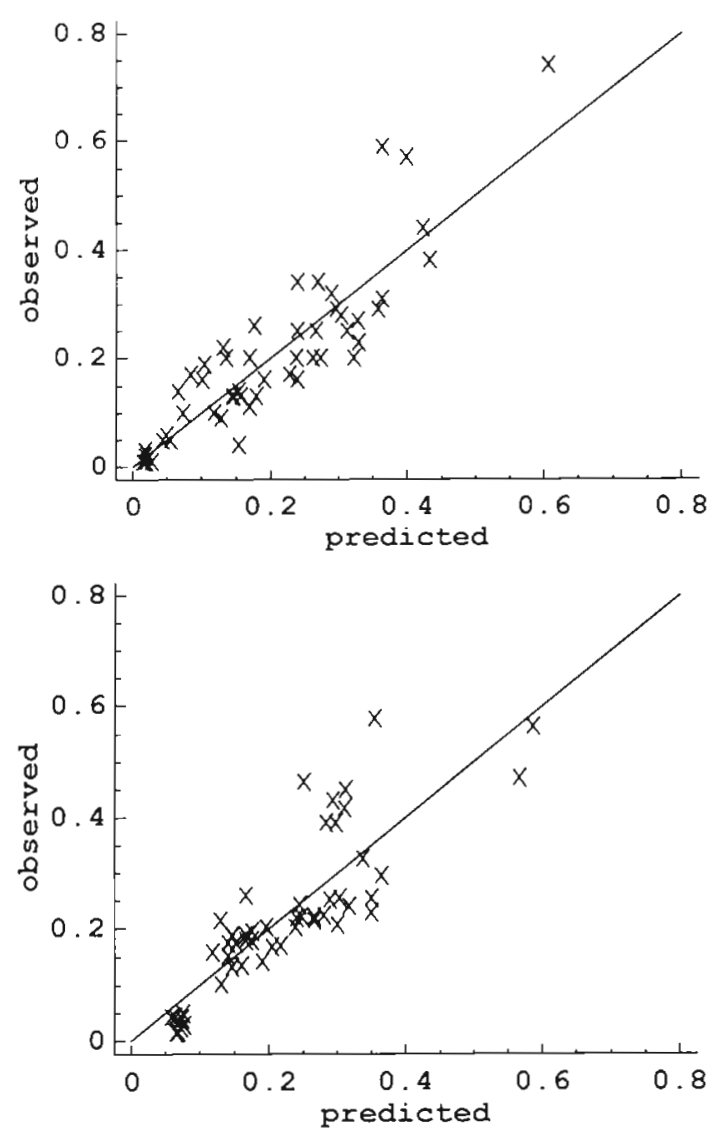

Fig. 6. Observed versus predicted values of chl a in 10 atoll lagoons in November 1995 (top) and March 1996 (bottom)

$0.03 \mu \mathrm{g} \mathrm{l}^{-1}$ ). In both seasons, the percentages of chl $\mathrm{a}$ in the $<1 \mu \mathrm{m}$ size fraction were usually above $50 \%$ in the studied atolls. The exceptions were Taiaro (38 to $39 \%$ ), Tekokota ( 23 to $38 \%$ ) and Tepoto Sud in the dry season $(4.5 \%)$ (Table 4 ).

Large differences in relative picoplankton group abundance were observed between the 2 sampling periods in some lagoons. Prochlorococcus were particularly abundant in Hiti lagoon $\left(281 \times 10^{3}\right.$ cells $\left.\mathrm{ml}^{-1}\right)$ during the rainy season (November) and in Haraiki $\left(210 \times 10^{3}\right.$ cells $\left.\mathrm{ml}^{-2}\right)$ during the dry season (March). Synechococcus were very abundant in Haraiki lagoon during both seasons but especially in March, when average abundance reached $370 \times 10^{3}$ cells $\mathrm{ml}^{-1}$. A large number of Synechococcus were also observed in Tepoto Sud lagoon in November $1995\left(278 \times 10^{3}\right.$ cells $\mathrm{ml}^{-1}$ ). Highest picoeukaryote abundances were recorded in Taiaro during both seasons, particularly in March $\left(7.4 \times 10^{3}\right.$ cells $\left.\mathrm{ml}^{-1}\right)$. The densities of the 3 picoplankton groups in surface coastal ocean waters ranged from $12 \times 10^{3}$ to $44 \times 10^{3}$ Prochlorococcus $\mathrm{ml}^{-1}$, $0.8 \times 10^{3}$ to $7.8 \times 10^{3}$ Synechococcus $\mathrm{ml}^{-1}$ and $0.2 \times 10^{3}$ to $0.7 \times 10^{3}$ picoeukaryote $\mathrm{ml}^{-1}$.
Estimating the contribution of picoplankton groups to biomass in November 1995 and March 1996

In November 1995 and March 1996, cytometric measurements were performed on fixed samples but the fit of the data was insufficient to estimate $\psi_{i}$. The picoeukaryotes were poorly preserved and as a result their RF were likely affected by the fixation. However, we were able to calculate $\psi_{i}^{\prime}$ (Table 2), as the fits of chl $a<1 \mu \mathrm{m}$ versus prokaryotic $R F$ were good $(\mathrm{p}<0.01)$ in all investigated lagoons except Reka-Reka (Fig. 6). The contribution of prokaryotic groups to total chl a was estimated by multiplying their contribution to the chl a $<1 \mathrm{\mu m}$ (calculated from Eq. 3) by the proportion of chl $a<1 \mu \mathrm{m}$. The contribution of picoeukaryotes to total chl a was estimated as the percentage of chl $a>1 \mu \mathrm{m}$.

Since all the samples were collected in the morning during TYPATOLL expeditions, the C biomass of the 3 groups was estimated using the average cellular $C$ contents calculated from the morning samples collected in Takapoto: $53 \mathrm{fg} \mathrm{C} \mathrm{cell}{ }^{-1}$ for Prochlorococcus $180 \mathrm{fg} \mathrm{C} \mathrm{cell}^{-1}$ for Synechococcus and $4970 \mathrm{fg} \mathrm{C}^{\mathrm{C}} \mathrm{cell}^{-1}$ for picoeukaryotes. For surface ocean waters, we used the values calculated for surface ocean waters surrounding Takapoto: $53 \mathrm{fg} \mathrm{C} \mathrm{Cell}^{-1}$ for Prochlorococcus, $191 \mathrm{fg} \mathrm{cell}^{-1}$ for Synechococcus and $2568 \mathrm{fg} \mathrm{C} \mathrm{cell}^{-1}$ for picoeukaryotes. The picoplankton carbon biomass (Table 4) varied from $0.2 \mu \mathrm{g} \mathrm{l}^{-1}$ in Tekokota to $79 \mathrm{\mu g} \mathrm{l}^{-1}$ in Haraiki (March). Prochlorococcus dominated the picoplankton biomass in only 1 lagoon: Hiti in November $(73 \%$ of chl a and $52 \%$ of $C$ ). The contribution of Synechococcus to picoplankton biomass was important in all lagoons except Reka-Reka, Taiaro and Tekokota. Its contribution was also important in Tepoto Sud but only in November, when they contributed to $73 \%$ of chl $a$ and $84 \%$ of C. Picoeukaryotes dominated the picoplankton biomass at Reka-Reka, Taiaro, Takapoto (in surface water) and Tekokota. They also dominated the picoplankton biomass at Tepoto Sud in March $(96 \%$ of $\mathrm{chl} a$ and $65 \%$ of $\mathrm{C}$ ). In surface ocean waters in November, Prochlorococcus contributed $51 \%$, Synechococcus $16 \%$ and picoeukaryotes $34 \%$, of picoplankton carbon, whereas in March their contributions were 42,12 and $46 \%$ respectively.

Estimating the contribution of picoplankton groups to primary production in November 1995 and March 1996

As for Takapoto data, the contribution of prokaryotic cells to total production was estimated by the percentage of carbon assimilation rate in the $<1 \mu \mathrm{m}$ size fraction. In both seasons, the percentages of carbon assimilation rate in the $<1 \mu \mathrm{m}$ size fraction were above $45 \%$ 
Table 5. Average \pm standard error of percentage of carbon assimilation rate $(C A R)$ in the $<1 \mu m$ size fraction; percentage contributions of Prochlorococcus (Proc), Synechococcus (Syn), and picoeukaryotes (Peuk) to CAR in surface atoll lagoon waters; and estimated primary production (PP). nm: no measurements

\begin{tabular}{|c|c|c|c|c|c|c|}
\hline Atoll & Date & $\mathrm{CAR}<1 \mu \mathrm{m}(\%)$ & CAR Proc $(\%)$ & CAR Syn $(\%)$ & CAR Peuk $(\%)$ & $P P\left(g C m^{-2} d^{-1}\right)$ \\
\hline Haraiki & $\begin{array}{l}\text { Nov } 1995 \\
\text { Mar } 1996\end{array}$ & $\begin{array}{l}70.7 \pm 1.0 \\
81.1 \pm 1.4\end{array}$ & $\begin{array}{r}7.1 \pm 3.0 \\
39.8 \pm 1.4\end{array}$ & $\begin{array}{l}63.6 \pm 3.0 \\
40.4 \pm 1.4\end{array}$ & $\begin{array}{l}29.3 \pm 1.6 \\
19.8 \pm 2.8\end{array}$ & $\begin{array}{l}0.34 \\
0.60\end{array}$ \\
\hline Hikueru & $\begin{array}{l}\text { Nov } 1995 \\
\text { Mar } 1996\end{array}$ & $\begin{array}{l}46.5 \pm 4.4 \\
65.8 \pm 3.7\end{array}$ & $\begin{array}{l}13.1 \pm 3.3 \\
10.5 \pm 0.1\end{array}$ & $\begin{array}{l}33.4 \pm 2.6 \\
48.9 \pm 0.4\end{array}$ & $\begin{array}{l}53.5 \pm 2.0 \\
40.6 \pm 0.5\end{array}$ & $\begin{array}{l}0.62 \\
0.62\end{array}$ \\
\hline Hiti & $\begin{array}{l}\text { Nov } 1995 \\
\text { Mar } 1996\end{array}$ & $\begin{array}{l}66.8 \pm 0.8 \\
53.3 \pm 1.1\end{array}$ & $\begin{array}{l}58.2 \pm 1.0 \\
16.1 \pm 0.3\end{array}$ & $\begin{array}{r}8.6 \pm 0.6 \\
37.3 \pm 0.8\end{array}$ & $\begin{array}{l}34.2 \pm 1.1 \\
46.6 \pm 1.1\end{array}$ & $\begin{array}{l}0.30 \\
0.34\end{array}$ \\
\hline Kauehi & $\begin{array}{l}\text { Nov } 1995 \\
\text { Mar } 1996\end{array}$ & $\begin{array}{l}71.7 \pm 2.3 \\
74.9 \pm 2.3\end{array}$ & $\begin{array}{l}40.7 \pm 3.7 \\
49.7 \pm 1.5\end{array}$ & $\begin{array}{l}31.1 \pm 3.6 \\
25.2 \pm 0.8\end{array}$ & $\begin{array}{l}28.2 \pm 0.9 \\
25.1 \pm 2.3\end{array}$ & $\begin{array}{l}1.04 \\
1.30\end{array}$ \\
\hline Marokau & $\begin{array}{l}\text { Nov } 1995 \\
\text { Mar } 1996\end{array}$ & $\begin{array}{l}50.3 \pm 1.3 \\
57.7 \pm 0.7\end{array}$ & $\begin{array}{l}31.3 \pm 3.9 \\
26.0 \pm 0.3\end{array}$ & $\begin{array}{l}18.4 \pm 4.5 \\
31.1 \pm 0.3\end{array}$ & $\begin{array}{l}50.3 \pm 2.8 \\
42.9 \pm 0.6\end{array}$ & $\begin{array}{l}0.66 \\
0.94\end{array}$ \\
\hline Nihiru & $\begin{array}{l}\text { Nov } 1995 \\
\text { Mar } 1996\end{array}$ & $\begin{array}{l}52.1 \pm 2.1 \\
52.5 \pm 8.5\end{array}$ & $\begin{array}{l}25.1 \pm 2.4 \\
24.5 \pm 4.0\end{array}$ & $\begin{array}{l}27.0 \pm 2.1 \\
28.0 \pm 4.6\end{array}$ & $\begin{array}{l}47.9 \pm 5.3 \\
47.5 \pm 8.6\end{array}$ & $\begin{array}{l}0.42 \\
0.49\end{array}$ \\
\hline Reka-Reka & $\begin{array}{l}\text { Nov } 1995 \\
\text { Mar } 1996\end{array}$ & $\begin{array}{l}45.4 \pm 1.1 \\
34.7 \pm 0.5\end{array}$ & $\begin{array}{l}\mathrm{nm} \\
\mathrm{nm}\end{array}$ & $\begin{array}{l}\mathrm{nm} \\
\mathrm{nm}\end{array}$ & $\begin{array}{l}54.2 \pm 1.0 \\
65.3 \pm 0.6\end{array}$ & $\begin{array}{l}0.07 \\
0.05\end{array}$ \\
\hline Taiaro & $\begin{array}{l}\text { Nov } 1995 \\
\text { Mar } 1996\end{array}$ & $\begin{array}{l}37.0 \pm 6.1 \\
32.0 \pm 5.1\end{array}$ & $\begin{array}{l}10.7 \pm 2.6 \\
16.5 \pm 2.7\end{array}$ & $\begin{array}{l}26.3 \pm 3.6 \\
15.5 \pm 2.5\end{array}$ & $\begin{array}{l}63.0 \pm 5.1 \\
68.0 \pm 5.1\end{array}$ & $\begin{array}{l}0.53 \\
0.88\end{array}$ \\
\hline Takapoto & Nov 1994 & $50.0 \pm 1.6$ & $5.8 \pm 0.5$ & $44.1 \pm 1.4$ & $50.0 \pm 1.6$ & 0.81 \\
\hline Tekokota & $\begin{array}{l}\text { Nov } 1995 \\
\text { Mar } 1996\end{array}$ & $\begin{array}{l}45.3 \pm 3.1 \\
23.7 \pm 0.7\end{array}$ & $\begin{array}{l}36.4 \pm 3.2 \\
20.9 \pm 0.6\end{array}$ & $\begin{array}{l}8.9 \pm 2.7 \\
2.8 \pm 0.1\end{array}$ & $\begin{array}{l}54.7 \pm 2.3 \\
76.3 \pm 0.7\end{array}$ & $\begin{array}{l}0.01 \\
0.01\end{array}$ \\
\hline Tepoto Sud & $\begin{array}{l}\text { Nov } 1995 \\
\text { Mar } 1996\end{array}$ & $\begin{array}{l}62.3 \pm 1.1 \\
15.1 \pm 0.3\end{array}$ & $\begin{array}{l}2.8 \pm 0.4 \\
2.7 \pm 0.1\end{array}$ & $\begin{array}{l}59.5 \pm 1.0 \\
12.4 \pm 0.3\end{array}$ & $\begin{array}{l}37.7 \pm 0.9 \\
84.9 \pm 0.3\end{array}$ & $\begin{array}{l}0.12 \\
0.14\end{array}$ \\
\hline Ocean & $\begin{array}{l}\text { Nov } 1995 \\
\text { Mar } 1996\end{array}$ & $\begin{array}{l}52.4 \pm 0.8 \\
57.4 \pm 1.4\end{array}$ & $\begin{array}{c}\mathrm{nm} \\
45.0 \pm 5.2\end{array}$ & $\begin{array}{c}\mathrm{nm} \\
12.4 \pm 5.4\end{array}$ & $\begin{array}{l}47.6 \pm 0.8 \\
42.6 \pm 2.4\end{array}$ & \\
\hline
\end{tabular}

in all atolls except in Reka-Reka in March (35\%), in Taiaro (37 and 32\%), Tekokota in March (24\%) and Tepoto Sud in March (15\%) (Table 5). The estimated contributions of picoplankton groups to primary production could be calculated for all atoll lagoons except Reka-Reka using their contributions to chl $a<1 \mu \mathrm{m}$ and the percentage of carbon assimilation rate $<1 \mu \mathrm{m}$. With some exceptions, picoplankton group contributions to carbon assimilation rate were very close to their contributions to chl a (Tables 4 \& 5). In Takapoto, the contribution of Prochlorococcus to carbon assimilation rate was much higher than what their contribution to chl a indicated (Tables $4 \& 5$ ), but this value considers only the upper layer of the lagoon. In Tepoto Sud (March), the contribution of Synechococcus to carbon assimilation rate was 4 times their contribution to chl a. In Hiti (November), picoeukaryote contribution to carbon assimilation rate was twice their contribution to chl a.

\section{Estimation of lagoon productivity}

We attempted to estimate lagoon primary production using the average in situ biomass-specific production, $P^{\mathrm{B}}$, measured in Takapoto and Tikehau lagoons be-

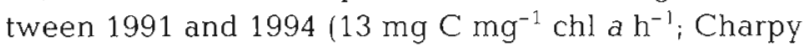

1996), the average chl a concentration and the estimated average depth of lagoons (Table 5). Estimated lagoon productivity ranged between $0.01 \mathrm{~g} \mathrm{C} \mathrm{m}^{-2} \mathrm{~d}^{-1}$ (Tekokota) and $1.3 \mathrm{~g} \mathrm{C} \mathrm{m}^{-2} \mathrm{~d}^{-1}$ (Kauehi).

\section{DISCUSSION}

\section{Picoplankton size}

At Takapoto the sizes calculated for the 3 groups are within the range of the data given in the literature (Table 6). The size of prokaryote cells is for the most part under $1 \mu \mathrm{m}$ in diameter for Prochlorococcus $\{0.54$ to $0.73 \mu \mathrm{m}$ ) and Synechococcus $(0.81$ to $0.99 \mu \mathrm{m})$. Above $1 \mu \mathrm{m}$ the cells are largely picoeukaryotes $(2.83$ to $3.26 \mu \mathrm{m}$ ). During the day, the size increased to a maximum value, then decreased. The average sizes of Prochlorococcus, Synechococcus and picoeukaryotes increased by 35,22 and $14 \%$, respectively.

\section{Vertical variations}

In Takapoto (November 1994), due to an unusual stratification of the water column in the lagoon envi- 
Table 6. Picoplankton groups cell size in different areas. FCM: flow cytometric measurement

\begin{tabular}{|lclll|}
\hline Group & Diameter $(\mathrm{\mu m})$ & Source & Method & Area \\
\hline Prochlorococcus & $0.6-0.8$ & Chisholm et al. (1988) & Size fraction FCM & Atlantic and Pacific \\
& 0.8 & Vaulot et al. (1990) & Size fraction FCM & Mediterranean \\
& $0.5-0.7$ & Morel et al. (1993) & Coulter Counter & Cultures \\
Synechococcus & $0.6-1$ & Blanchot \& Rodier (1996) & Size fraction FCM & Pacific \\
& $0.9-2.2$ & Waterbury et al. (1979) & Microscopy & Atlantic \\
& $0.8-1.0$ & Johnson \& Sieburth (1979) & Microscopy & Cultures \\
Picoeukaryotes & 1 & Verity et al. (1992) & Microscopy & Pacific \\
& $0.6-1$ & Blanchot \& Rodier (1996) & Size fraction FCM & Pacific \\
& $0.6-3$ & Blanchot \& Rodier (1996) & Size fraction FCM & Pacific \\
& 2.3 & Campbell et al. (1994) & Microscopy FCM & Pacific \\
\hline
\end{tabular}
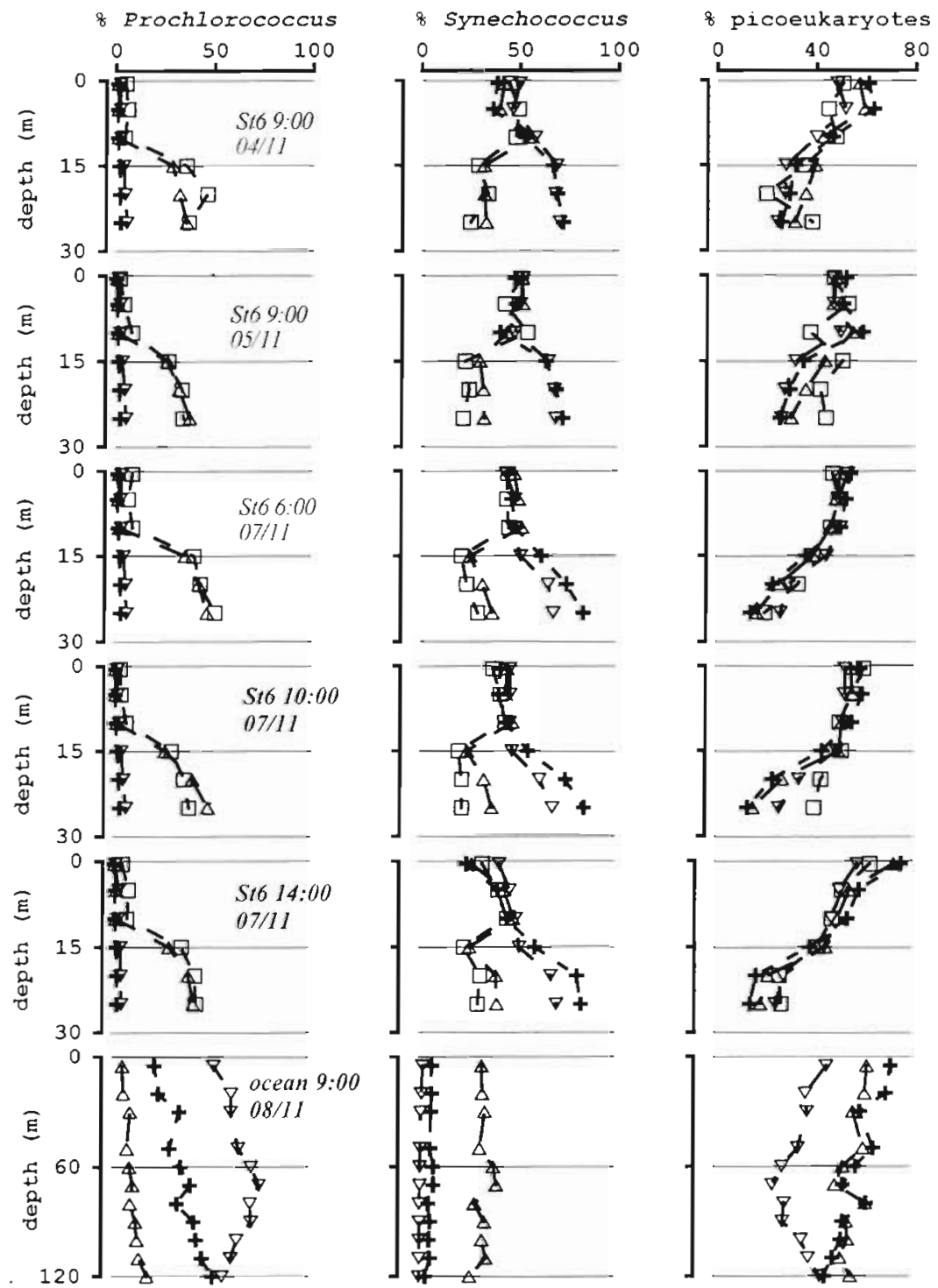

Fig. 7. Depth profiles of $(+)$ percentage of red fluorescence, $(\Delta)$ percentage contribution to $c h l a,(\nabla)$ percentage contribution to picoplankton $C$ and $(\square)$ percentage contribution to carbon assimilation rate in 8 depth profiles in Takapoto lagoon and in surrounding oceanic waters (November 1994) ronment (Charpy 1996) the picoplankton community structure of the upper layer $(0$ to $10 \mathrm{~m})$ was dominated by picoeukaryotes $(54 \%)$. In the deeper layer (15 to $30 \mathrm{~m}$ ) the 3 groups were equally abundant in terms of RF.

For Prochlorococcus, which are able to photoacclimate to low light intensity (large increase of divinyl chlorophyll b; Partensky et al. 1996), $\psi$ values were 8 times higher in the deeper layer (111) than in the upper layer (14) (Table 2). However, for Synechococcus the trend was reversed: $\psi$ values were 3 times lower in the deeper layer (3.3) than in the upper layer (10.8). Finally, for picoeukaryotes $\psi$ values were similar in the upper and lower part of the water column. In the deeper layer, the higher chl a content and productivity of Prochlorococcus versus that of Synechococcus confirms the former's adaptation to low light environments (Moore et al. 1995). In contrast, during TYPATOLL experiments picophytoplankton was uniformly distributed in the water column due to frequent windy conditions. Surface samples were thus representative of the entire water column.

\section{Comparison between different estimates of picoplankton group dominance}

The dominance of the different picoplankton groups varied with the method used to estimate their relative 
importance as reported by Li (1995): (1) percentage of red fluorescence (RF), (2) percentage of chl a calculated using regression estimated values of $\psi_{1}$ (3) percentage of carbon, (4) percentage of primary production. In the 5 depth profiles in Takapoto lagoon where picoplankton biomass and primary production were measured simultaneously (Fig. 7), firstly we observed that picoplankton group dominance estimated by flow cytometric analysis, i.e. percentages of RF and percentages of picoplankton $C$ (via size/FSC estimations) are similar. Secondly, values estimated by their contribution to chl a were similar to values estimated by their contribution to primary production. This result concords with the observations of Li $(1994,1995)$ on the picoplankton of the central North Atlantic. Indeed, this author observed that differences between the contributions of picoplankton groups to chl a and primary production based on the measurements of ${ }^{14} \mathrm{C}$ uptake rate per cell obtained by flow sorting were small (28 vs $19 \%$ for Prochlorococcus, 11 vs $13 \%$ for Synechococcus and 61 vs $68 \%$ for picoeukaryotes).

Finally, Prochlorococcus dominance is strongly underestimated with methods (1) and (3) compared with method (2), whereas methods (1), (2), (3) and (4) appear equally efficient for picoeukaryotes. This is likely due to an underestimation of Prochlorococcus in near surface waters due to a lack of sensitivity of the FACScan. Prokaryotic cell estimations vary significantly at different depths. In the deeper layer of Takapoto lagoon, the pigment content and the carbon assimilation rate per cell of Prochlorococcus were high. Whereas with Synechococcus, the RF and C content per cell increased with depth without an increase in chl a content and productivity.

In ocean waters, Prochlorococcus dominance was overestimated with method (3) (carbon contribution) and method (1) (red fluorescence) compared with method (2) (chl a contribution). The opposite situation accurs for Synechococcus. The estimation of chl a content per unit fluorescence $\psi$, in Takapoto oceanic waters was made using only 1 profile with all depths pooled, and was probably not reliable. Indeed, the $\psi_{\text {, }}$ calculations in lagoonal waters have shown that this parameter varied with depth. In fact the pigment content of raised cells is known to increase when the light exposition decrease (Cailliau et al. 1996, Shimada et al. 1996). In addition there might have been variations in the carbon content of the 3 picoplankton groups with depth.

\section{Temporal variations}

The large differences of picoplankton community structure observed between the 2 TYPATOLL expedi- tions in some lagoons were independent of season. Indeed, Prochlorococcus were abundant in Haraiki, Marokau and Nihiru in March and in Hiti in November while Synechococcus were very abundant in Haraiki in March and in Tepoto Sud in November. A similar pattern was noted in Takapoto between 1991 and 1994 and in Tikehau (2 other Tuamotu atolls) between 1983 and 1985, where large differences in phytoplankton biomass as chl a were recorded independently of season (Charpy 1996). Therefore, we did not see the seasonal variations in picoplankton community structure observed by Campbell et al. (1997) in the subtropical North Pacific Ocean where the abundance of Prochlorococcus typically peaked in the summer, Synechococcus in the winter and picoeukaryotes in the spring. It seems that in the Tuamotu archipelago, small-temporal-scale stress (wind, storm, etc.) has a larger effect upon the community structure than the effect of season. Typically, strong winds can induce resuspension of sedimented particulate materials including benthic microalgae, which can lead to a change in the size fractionation of chl a. A significant relationship has been established between wind intensity and sediment resuspension (Clavier et al. 1995). Furthermore, the perturbation of the water-sediment interface induced by storms may release nutrients trapped in the sediments. In Tikehau lagoon, for instance, nutrient concentrations of sediment pore water reached maximum values of $130 \mu \mathrm{M} \mathrm{NH}_{4}$, $7 \mu \mathrm{M} \mathrm{PO}_{4}$ and $30 \mu \mathrm{M} \mathrm{SiO}_{2}$ between 4 and $6 \mathrm{~cm}$ below the surface of the sediments (Charpy-Roubaud et al. 1997).

\section{Relation between picoplankton biomass and commu- nity structure, and atoll geomorphology}

In spite of the large variations in structure, some general trends can be observed. All atoll lagoons except Taiaro and Tekokota were dominated by prokaryotic plankton. With the exception of the deeper lagoons, Kauehi (45 m) and Marokau (30 m), where growth of Prochlorococcus appears to have been promoted, the dominant group was Synechococcus. Prochlorococcus are better adapted than Synechococcus for photosynthesis in blue-dominated light (Shimada et al. 1996). Synechococcus are well known to be abundant only in the upper part of the photic layer (Blanchot et al. 1992, Blanchot \& Rodier 1996). The high chl a concentration observed in the Reka-Reka lagoon can be explained as a resuspension of benthic microphytes due to the shallowness of the lagoon $(1.5 \mathrm{~m})$. However, these benthic organisms were not considered when flow cytometric measurements were made, and therefore the contribution of picoplankton groups to chl a 
could not be estimated. In a previous paper (Charpy et al. 1997), we demonstrated that phytoplankton biomass (chlorophyll concentration) was inversely related to the water exchange between lagoon and ocean. The decrease of chlorophyll concentration with the degree of openness of atoll lagoons may be related to a simple 'dilution' of the lagoon by the low-chlorophyll oceanic waters inside the open atolls. This may explain the very low phytoplankton biomass in Tekokota, a lagoon with high exchange with oceanic waters. The large dominance of picoeukaryotes observed in Taiaro may be due to the high salinity of the lagoon (>40 PSU).

Biotic factors can also affect the picoplankton biomass and community structure. There are a variety of macroinvertebrates that feed on ultra-plankton (Jørgensen et al. 1984, Vacelet 1984, Vacelet \& Boury-Esnault 1995). Reiswig (1971) found that coral reef sponges are a significant sink for plankton. Indeed, Pile et al. (1996) observed that Prochlorococcus was filtered by sponges with the highest efficiency (93\%), followed by Synechococcus (89\%) and picoeukaryotes (72\%). In coral reef waters sponges significantly decreased concentrations of Prochlorococcus and Synechococcus while increasing those of autotrophic picoeukaryotes (Pile 1997). Sponges are thus capable of altering community structure. In atoll lagoons, sponges and other filter feeders are mainly located on hard substrates: coral reef pinnacles or fringing reefs. The density of hard substrate varies between lagoons. Nihiru and Tekokota lagoons have a high percentage of hard substrate relative to surface area while Tepoto Sud and Taiaro have a low percentage (Dufour \& Harmelin-Vivien 1997). The metabolism of cultivated pearl oysters, particularly abundant in Takapoto, can also affect the phytoplankton biomass (Charpy et al. 1997). Indeed, waste products from the reared Pinctada margaritifera stock in Takapoto lagoon enhanced the growth rates of phytoplankton by decreasing the regeneration time of the nutrients (Vacelet et al. 1996). Filtration experiments performed on Takapoto Pearl oysters demonstrated that $P$. margaritifera feed only on picoeukaryotes (Blanchot urupubl.). Zooplankton can also have a strong effect on picoplankton abundance and community structure. In Tikehau lagoon, animals $>35 \mu \mathrm{m}$ grazed more than $60 \%$ of primary production. Inorganic excretion constituted 32 and $18 \%$ of the phytoplankton nitrogen and phosphorus requirements (Le Borgne et al. 1989). Zooplankton biomass was studied in the investigated atolls but the data has not been processed yet.

\section{Comparison between lagoon and open ocean waters}

With the exception of Tekokota, picoplankton biomass was 2 to 10 times higher in atoll lagoons than in surrounding surface waters. On the other hand, integrated picoplankton biomass observed in Takapoto ocean waters (1242 $\mathrm{mg} \mathrm{C} \mathrm{m}^{-2}$ in the upper $120 \mathrm{~m}$ ) was considerably higher than the integrated biomass found in lagoon waters. The picoplankton community structure was dominated by Synechococcus in atoll lagoons and Prochlorococcus in the surrounding ocean waters. This dominance of Prochlorococcus, already demonstrated in subtropical areas (Campbell \& Vaulot 1993, Campbell et al. 1994, 1997) and tropical areas (Blanchot \& Rodier 1996), would appear to be a common feature in the Pacific Ocean. This switch in dominance from Prochlorococcus to Synechococcus in lagoons may be due to 3 factors: (1) Photoinhibition in shallow lagoons. Photoinhibition of Prochlorococcus in shallow waters was observed in Takapoto. (2) Difference in nutrient availability. Differences in nutrient concentrations between lagoon and ocean were observed in Tuamotu Archipelago. In Takapoto and Tikehau, phosphate and silicate concentrations were lower in the lagoons than in the surrounding ocean water (Sournia \& Ricard 1976, Charpy-Roubaud et al. 1990, Charpy 1996). $\mathrm{N}_{2}$-nitrogen fixation by Synechococcus was reported in Tikehau lagoon by Charpy-Roubaud et al. (1997); this process requires extra P uptake and may therefore be responsible for phosphorus depletion. Data from the Great Astrolabe Reef (Fiji) and Tuamotu atoll lagoons (Blanchot \& Charpy 1997) appear to indicate that when the photic layer is $\mathrm{N}$ depleted $\left(\mathrm{NO}_{3}+\right.$ $\mathrm{NO}_{2}<0.1 \mu \mathrm{M}$ ), Prochlorococcus is the major component of the integrated carbon biomass. In the layers where $\mathrm{NO}_{3}+\mathrm{NO}_{2}$ concentration $>0.1 \mu \mathrm{M}$, picoeukaryotes constitute the major component in both atolllagoon and near-shore waters, whereas when $\mathrm{NO}_{3}+$ $\mathrm{NO}_{2} \approx 0.1 \mu \mathrm{M}$, small concentrations of $\mathrm{NH}_{4}{ }^{+}$appear to promote Synechococcus abundance. The turnover time of $\mathrm{N}$ and $\mathrm{P}$ might be lower in lagoon waters because part of the remineralization process occurs in the sediments and the pool of pore water nutrients is released during storms. (3) Difference in grazing. We argued above that grazing by benthic macroinvertebrates, organisms absent in ocean waters, could significantly affect the picoplankton abundance and community structure. In addition, lagoon zooplankton might be different from ocean zooplankton and therefore have a different grazing impact on picoplankton. Successive blooms of different groups of zooplankton can generate quantitative and qualitative differences in the control of the pico- and namoplankton populations, and dominance of a specific group of grazers can alter the size distribution pattern of food particles. In a recent study G. Gorsky, M. J Dinet, J. Blanchot \& I. Palazzoli (unpubl.) reported that the larvacean Megalocercus huxleyi efficiently filtered, assimilated and aggregated into fecal pellets pico- and nanoplankton 
(submicronic particles included). Blooms of thaliaceans, larvaceans, pteropods and copepods were reported in Tikehau and Rangiroa lagoons (Michell et al. 1971, Le Borgne \& Moll 1986, Le Borgne et al. 1989). Salps, larvaceans, doliolids and thecosome-pteropods are known to feed on particles at least 3.5 orders of magnitude smaller than their own size (Fortier et al. 1994). Such peculiar blooms of small particle feeders could alter the community structure from small-sizefraction dominance (prokaryotic) to large-size-fraction dominance (eukaryotic). Another hypothesis to explain the differences between oceanic and lagoonal picoplankton community structure is viral infection. Indeed, Blanchot \& Rodier (1996) consider that viral infection could be responsible for controlling of the abundance of prokaryotic phytoplankton, and coastal waters are more suitable than ocean waters for cyanophage infection and growth (Boehme et al. 1993. Suttle \& Chan 1994).

Acknowledgements. This work was carried out in French Polynesia within the framework of the ORSTOM CYEL and TYPATOLL programs, the PNRCO program (Programme National sur les Récifs coralliens) and the PGRN with the financial participation of the DOM-TOM Ministry, the Ministry for Research and Technology, the European Fund (VI FED-PTOM) and the territorial government of French Polynesia. We thank the ALIS crew for their kind and efficient help on board, J.-P. Rochette for his technical assistance and G. Haumani and his entire team for their help in the field and at the EVAAM station at Takapoto. We also thank C. Navarette, $M$. Rodier and A. Le Bouteiller for comments. We also appreciate the comments of reviewers.

\section{LITERATURE CITED}

Binder BJ, Chisholm SW, Olson RJ, Frankel SL, Worden AZ (1996) Dynamics of picophytoplankton, ultraphytoplankton and bacteria in the central equatorial Pacific. Deep Sea Res I 43:907-931

Blanchot J, Charpy L (1997) Picophytoplanktonic community structure in the subtropical Pacific Ocean: a comparison between the offshore and coastal ocean and the closed and open lagoons, in relation with the nitrogen nutrient availability. Proc 8th Int Coral Reef Symp, Panama 1 $821-826$

Blanchot J, Charpy L, Le Borgne R (1989) Size composition of particulate organic matter in the lagoon of Tikehau atoll (Tuamotu archipelago). Mar Biol 102:329-339

Blanchot J, Rodier M (1996) Phytoplankton abundance and biomass in the western tropical Pacific Ocean during the 1992 El Niño year: results from flow cytometry. Deep Sea Res I 43:877-895

Blanchot J, Rodier M, Le Bouteiller A (1992) Effect of El Niño oscillation on the distribution and abundance of phytoplankton in the Western Pacific tropical ocean along $165^{\circ} \mathrm{E}$. J Plankton Res 14:137-156

Boehme J, Frisher ME, Jiang SC, Kellogg CA, Pichard S, Rose JB, Steinway C, Paul JH (1993) Viruses, bacterioplankton and phytoplankton in the southeastern Gulf of Mexico: distribution and contribution to oceanic DNA Pools. Mar Ecol Prog Ser 97:1-10
Cailliau C, Claustre H, Vidussi F, Marie D, Vaulot D (1996) Carbon biomass, and growth rates as estimated from ${ }^{14} \mathrm{C}$ pigment labelling, during photoacclimation in Prochlorococcus CCMP 1378. Mar Ecol Prog Ser 145:209-221

Campbell L, Liu H, Nolla HA, Vaulot D (1997) Annual variability of phytoplankton and bacteria in the subtropical North Pacific Ocean at Station ALOHA during the 1991-1994 ENSO event. Deep Sea Res I 44:167-192

Campbell L, Nolla HA, Vaulot D (1994) The importance of Prochlorococcus to community structure in the Central North Pacific Ocean. Limnol Oceanogr 39:954-961

Campbell L, Vaulot D (1993) Photosynthetic community structure in the subtropical Pacific Ocean near Hawaii station Aloha). Deep Sea Res 1 40:2043-2060

Charpy L (1992) The CYEL program: energy flow and organic-matter cycling in atoll lagoons. UNEP Reg Seas Rep Stud 147:69-75

Charpy L (1996) Phytoplankton biomass and production in two Tuamotu atoll lagoons (French Polynesia). Mar Ecol Prog Ser 145:133-142

Charpy L, Blanchot J (1996) Prochlorococcus contribution to phytoplankton biomass and production of Takapoto atoll (Tuamotu archipelago). CR Acad Sci Paris Life Sci 319: 131-137

Charpy L, Blanchot J, Lo L. (1992) Contribution des cyanobactéries (Synechococcus spp.) à la production phytoplanctonique dans un lagon d'atoll fermé (Takapoto. Tuamotu, Polynésie Française). CR Acad Sci Paris Sér III 314: 395-401

Charpy L, Dufour P, Garcia N (1997) Particulate organic matter in sixteen Tuamotu atoll lagoons (French Polynesia). Mar Ecol Prog Ser 151:55-65

Charpy-Roubaud CJ, Charpy L, Cremoux JL (1990) Nutrient budget of the lagoonal waters in an open South Pacific atoll (Tikehau Tuamotu French Polynesia). Mar Biol 107: $67-73$

Charpy-Roubaud CJ, Charpy L, Larkum AW (1997) Contribution of $\mathrm{N}_{2}$ fixation to $\mathrm{N}$ productivity of the lagoon of Tikehau. Proc 8th Int Coral Reef Symp, Panama 1:803-808

Chevallier JP, Salvat B (1976) Etude géomorphologique et biologique de l'atoll fermé de Taiaro (Tuamotu, Polynésie Française). Cah Pac 16:169-202

Chisholm SW, Frenkel SL, Georicke R, Olson RJ, Palenik B, Waterbury JB, West-Johnsrud L, Zetttler ER (1992) Prochlorococcus marinus nov. gen. nov. sp. An oxytrophic marine prokaryote containing divinyl chlorophyll $a$ and $b$. Arch Mikrobiol 157:297-300

Chisholm SW, Olson RJ, Zetttler ER, Goerike R, Waterbury JB, Welschmeyer NA (1988) A novel free-living prochlorophyte abundant in the oceanic euphotic zone. Nature $334: 340-343$

Clavier J, Chardy P, Chevillon C (1995) Sedimentation of particulate matter in the south-west lagoon of New Caledonia: spatial and temporal patterns. Estuar Coast Shelf Sci 40:281-294

Dufour P, Harmelin-Vivien M (1997) A research program for a typology of atoll lagoons: strategy and first results. Proc 8th Int Coral Reef Symp, Panama 1:843-848

Durand MD, Olson RJ (1996) Contributions of phytoplankton light scattering and cell concentration changes to diel variations in beam attenuation in the equatorial Pacific from flow cytometric measurements of pico-, ultra- and namoplankton. Deep Sea Res 43:891-906

Dusenberry JA, Frankel SL (1994) Increasing the sensitivity of a FACScan flow cytometer to study oceanic picoplankton. Limnol Oceanogr 39:206-209

Fitzwater SE, Knauer GA, Martin JH (1982) Metal contamina- 
tion and its effect on primary production measurements. Limnol Oceanogr 27:544-551

Fortier L, Le Fèvre J, Legendre L (1994) Export of biogenic carbon to fish and to the deep ocean: the role of large planktonic microphages. J Plankton Res 16(7):809-839

Johnson PW, Sieburth JMcN (1979) Chroococcoid cyanobacteria in the sea: a ubiquitous and diverse phototrophic biomass. Limnol Oceanogr 24:928-935

Jørgensen CB, Kiørboe T, Møhlenberg F, Rijsgărd HU (1984) Ciliary and mucus-net filter feeding, with special reference to the fluid mechanical characteristics. Mar Ecol Prog Ser 15:283--292

Le Borgne RP, Blanchot J, Charpy L (1989) Zooplankton of the atoll of Tikehau (Tuamotu Archipelago) and its relationship to particulate matter. Mar Biol 102:341-353

Le Borgne R, Moll P (1986) Growth rate of the salp Thalia democratica in Tikehau atoll (Tuamotu is.). Oceanogr Trop $21: 23-29$

Li WK (1994) Primary production of prochlorophytes, cyanobacteria, and eukaryotic ultraphytoplankton: measurements from flow cytometric sorting. Limnol Oceanogr 38 : $169-175$

Li WK (1995) Composition of ultraphytoplankton in the central North Atlantic. Mar Ecol Prog Ser 122:1-8

Li WK, Zohary T, Yacobi YZ, Wood M (1993) Ultraphytoplankton in the eastern Mediterranean Sea: towards deriving phytoplankton biomass from cytometric measurements of abundance, fluorescence and light scatter Mar Ecol Prog Ser 102:79-87

Michell A, Colin C, Desrosieres R, Oudot C (1971) Observations sur l'hydrologie et le plancton des abords et de la zone des passes de l'atoll Rangiroa (Archipel des Tuamotus, Ocean Pacifique centrall. Cah ORSTOM Ser Oceanogr 9:375-402

Moore LR, Goericke R, Chisholm SW (1995) Comparative physiology of Synechococcus and Prochlorococcus: influence of light and temperature on growth, pigments, fluorescence and absorptive properties. Mar Ecol Prog Ser 116:259-275

Morel A (1991) Optics of marine particles and marine optics. In: Particles analysis in oceanography. Proceedings of the NATO Advanced Study Institute of Individual Cell and Particle Analysis in Oceanography. Aquatifreda di Maratea, Italy, 21-30 October 1990. Springer, Berlin, p $141-188$

Morel A, Ahn YH, Partensky F, Vaulot D, Claustre H (1993) Prochlorococcus and Synechococcus: a comparative study of their optical properties in relation to their size and pigmentation. J Mar Res 51:617-649

Olson RJ, Chisholm SW, Zettler ER, Altabet MA, Dusenberry JA (1990) Spatial and temporal distributions of prochlorophyte picoplankton in the North Atlantic Ocean. Deep Sea Res 37:1033-1051

Olson RJ, Zettler ER, Anderson OK (1989) Discrimination of eukaryotic phytoplankton cell types from light scatter and autofluorescence properties measured by flow cytometry. Cytometry 10:636-643

Olson RJ, Zettler ER, DuRand MD (1993) Phytoplankton analysis using flow cytometry. In: Kemp PF, Sherr BF, Sherr EB, Cole $J J$ (eds) Handbook of methods in aquatic microbial ecology. Lewis Publ, Boca Raton, p 175-186

Partensky F, Blanchot J, Lantoine F, Neveux J, Marie D (1996) Vertical structure of picophytoplankton at different

Editorial responsibility: Otto Kinne (Editor),

Oldendorf/Luhe, Germany trophic sites of the tropical northeastern Atlantic Ocean. Deep Sea Res I 43:1191-1213

Pile AJ (1997) Finding Reiswigs missing carbon: quantification of sponge feeding using dual beam flow cytometry. Proc 8th Int Coral Reef Symp, Panama 2:1403-1410

Pile A.J, Patterson MR, Witman JD (1996) In situ grazing on plankton $<10 \mu \mathrm{m}$ by the boreal sponge Mycale lingua. Mar Ecol Prog Ser 141:95-102

Poli G, Salvat B (1976) Etude bionomique d'un lagon d'atoll totalement fermé: TAIRAO. Cah Pac 19:227-252

Reiswig HM (1971) Particle feeding in natural populations of three marine demosponges. Biol Bull Mar Biol Lab Woods Hole 141:568-591

Salvat B, Richard G (1985) Atoll de Takapoto, Archipel des Tuamotu. Proc 5th Int Coral Reef Congr, Tahiti 1:325-377

Shimada A, Hasegawa $T$, Umeda I, Kadoya N, Maruyama T (1993) Spatial mesoscale patterns of West Pacific picophytoplankton as analysed by flow cytometry: their contribution to subsurface chlorophyll maxima. Mar Biol 115: 209-215

Shimada A, Maruyama T, Miyachi S (1996) Vertical distribution and photosynthetic action spectra of two oceanic picophytoplankters, Prochlorococcus marinus and Synechococcus sp. Mar Biol 127:15-23

Sournia A, Ricard M (1976) Données sur l'hydrologie et la productivité du lagon d'un atoll fermé (Tuamotu lles Tuamotu). Vie Milieu 26:2:243-279

Strathmann RR (1967) Estimating the organic carbon content of phytoplankton from cell volume or plasma volume. Limnol Oceanogr 12:411-418

Suttle CA, Chan AM (1994) Dynamics and distribution of cyanophages and their effect on marine Synechococcus spp. Appl Environ Microbiol 60:3167-3174

Vacelet E, Arnoux A. Thomassin B (1996) Particulate material as an indicator of pearl-oyster excess in the Takapoto lagoon (Tuamotu, French Polynesia). Aquaculture 144: 133-148

Vacelet J (1984) Les éponges dans les récifs actuels et fossiles. Océanis 10(1):99-110

Vacelet J, Bourry-Esnault N (1995) Carnivorous sponges. Nature 373(6512):333-335

Vaulot D (1989) CYTOPC: processing software for flow cytometric data. Signal Noise 2:6-7

Vaulot D, Courties C, Partensky F (1989) A simple method to preserve oceanic phytoplankton for flow cytometric analyses. Cytometry 10:629-635

Vaulot D, Partensky F, Neveux J, Fauzi R, Mantoura C, Llewellyn CA (1990) Winter presence of prochlorophytes in surface water of the northwestern Mediterranean Sea. Limnol Oceanogr 35:1156-1164

Verity PG, Robertson CY, Tronzo CR, Andrews MG, Nelson JR, Sieracki ME (1992) Relationships between cell volume and the carbon and nitrogen content of marine photosynthetic nanoplankton. Limnol Oceanogr 37:1434-1446

Waterbury JB, Watson SW, Guillard RR, Brand LE (1979) Widespread occurrence of a unicellular marine plankton cyanobacteria. Nature 277:293-294

Yentsch CM, Campbell JW (1991) Phytoplankton growth perspectives gained from flow cytometry. J Plankton Res 13(Suppl):83-108

Yentsch CS, Menzel DW (1963) A method for the determination of phytoplankton chlorophyll and phaeophytin by fluorescence. Deep Sea Res 10:221-231

Submitted: July 21, 1997; Accepted: November 5, 1997

Proofs received from author(s): January 12, 1998 